\title{
PENGGUNAAN Trichoderma sp. DAN PGPR UNTUK MENGENDALIKAN PENYAKIT PADA TANAMAN STRAWBERRY DI RURUKAN (MAHAWU)
}

\author{
APPLICATION OF Trichoderma sp. and PGPR TO CONTROL DISEASE OF STRAWBERRY \\ AT RURUKAN (MAHAWU)
}

\author{
Caroulus S. Rante, Elisabet R.M. Meray, Daisy S. Kandowangko, Max M. Ratulangi, \\ Moulwy F. Dien, dan Dantje T. Sembel")
}

*)Fakultas Pertanian Unsrat Manado

\begin{abstract}
Study aims (a) to determine the effectiveness of Trichoderma sp., combination PGPR and Trichoderma sp., and PGPR to the development of diseases that attack strawberry plants, (b) to study the effect of application of Trichoderma sp., combination PGPR and Trichoderma sp. and PGPR for strawberry production. The experiment was conducted in the village Rurukan (Mahawu), subdistrict Tomohon Timur. Study lasted from March to August 2013. Experiments using a randomized block design with 4 treatments, as follows: Treatment $A=$ Trichoderma sp., Treatment $B=$ PGPR, Treatment $C=$ combination of Trichoderma sp. and PGPR, and Treatment $\mathrm{D}=$ Control. The experiment was repeated 4 times. Data were analyzed using Minitab software ver. 14. Things that observed the symptoms of disease, number of shoots, roots and heavy weight of strawberries. The results showed that strawberry plants are not attacked by various diseases. Fungus Verticillium sp. encountered attack strawberry plants with very low intensity. The average number of shoots ever encountered on the 6.25 shoots PGPR treatment and lowest in the control treatment, ie 2.20 shoots . The average weight of the heaviest roots found in the PGPR treatment and 68.75 grams of the lowest in the control treatment, which is 13.50 grams. The average weight of the fruit of the highest found in the 731.25 grams of PGPR treatment and lowest in the control treatment fruit weighing 417.50 grams.
\end{abstract}

Keywords : Trichoderma sp., Verticilium sp., PGPR, Mahawu

\section{ABSTRAK}

Penelitian bertujuan (a) untuk mengetahui efektivitas dari Trichoderma sp., PGPR serta Kombinasi Trichoderma sp. dan PGPR terhadap perkembangan penyakit yang menyerang tanaman stroberi, (b) untuk mempelajari pengaruh aplikasi Trichoderma sp., PGPR serta Kombinasi Trichoderma sp. dan PGPR terhadap produksi stroberi. Penelitian dilaksanakan di desa Rurukan (Mahawu), Kecamatan Tomohon Timur, Kota Tomohon. Penelitian berlangsung sejak bulan Maret sampai dengan Agustus 2013. Percobaan menggunakan Rancangan Acak Kelompok dengan 4 perlakuan, sebagai berikut: Perlakuan A = Trichoderma sp., Perlakuan B $=$ PGPR, Perlakuan $C=$ Kombination of Trichoderma $\mathrm{sp}$. and PGPR, Perlakuan $\mathrm{D}=$ Control. Percobaan diulang sebanyak 4 kali. Data dianalisis dengan menggunakan software Minitab ver. 14. Hal-hal yang diamati yakni gejala serangan penyakit, jumlah tunas, berat akar dan berat buah stroberi. Hasil pengamatan menunjukkan bahwa tanaman stroberi tidak terserang oleh berbagai macam penyakit. Jamur Verticilium sp. dijumpai menyerang tanaman stroberi dengan intensitas yang sangat rendah. Rata-rata jumlah tunas terbanyak dijumpai pada perlakuan PGPR yakni 6,25 tunas dan terendah pada perlakuan kontrol, yakni 2,20 tunas. Rata-rata berat akar terberat dijumpai pada perlakuan PGPR yakni 68,75 gram dan terendah pada perlakuan kontrol, yakni 13,50 gram. Rata-rata berat buah yang tertinggi dijumpai pada perlakuan PGPR yakni 731,25 gram dan terendah pada perlakuan kontrol dengan berat buah 417,50 gram.

Kata kunci : Trichoderma sp., Verticilium sp., PGPR, Mahawu 


\section{PENDAHULUAN}

Stroberi adalah tanaman buah berupa herba yang ditemukan pertama kali di Chili. Salah satu spesies tanaman stroberi yaitu Fragaria chiloensis L., menyebar ke berbagai negara Amerika, Eropa dan Asia. Stroberi yang ditemukan di pasar swalayan adalah hibrida yang dihasilkan dari persilangan $F$. virgiana $L$. var Duchesne asal Amerika Utara dengan $F$. chiloensis $L$. var Duchesne asal Chili. Persilangan itu menghasilkan hibrid yang merupakan stroberi modern (komersil) Fragaria x annanassa var Duchesne (Kurnia, 2005).

Stroberi merupakan salah satu buahbuahan yang mempunyai nilai ekonomi tinggi. Khusus di Propinsi Sulawesi Utara, tanaman ini dibudidayakan baru sekitar 4-5 tahun yang lalu. Belum ada laporan secara melembaga tentang serangan hama dan penyakit, khususnya terhadap tanaman stroberi di Sulawesi Utara. Di beberapa daerah, misalnya Cipanas dan Bandung (Jawa Barat), tanaman stroberi banyak dijumpai terserang oleh jamur Verticillium sp., yang menyebabkan daun berwarna kecoklatan kemudian mengering dan akhirnya mati.

Pengendalian penyakit yang menyerang tanaman perlu mendapat perhatian karena selama ini pengendalian yang dilakukan petani masih bertumpu pada aplikasi pestisida sintetik yang kurang ekonomis karena digunakan secara berlebihan dan tidak teratur serta berdampak negatif pada pencemaran lingkungan, keracunan pada manusia, resistensi hama dan mematikan musuh alami. Oleh karena itu perlu menggunakan konsep pengendalian sesuai prinsip PHT.

Penggunaan biopestisida merupakan salah satu perangkat PHT yang menduduki posisi srtrategis dalam menciptakan pertanian berwawasan lingkungan. Salah satu jenis cendawan yang digunakan sebagai biopestisida (mikroba antagonis) adalah Trichoderma spp. Baker and Cook (1974), menyatakan bahwa mekanisme antagonis dari Trichoderma spp. adalah berupa kompetisi, parasitisme, antibiosis dan lisis. Berdasarkan mekanisme-mekanisme tersebut maka Trichoderma spp. memiliki potensial untuk dikembangkan sebagai agens hayati. Sustiyah dan
Mulyani (2003) melaporkan bahwa jamur T. koningii yang diisolasi dari tanah gambut pedalaman di Kecamatan Sebangau, memiliki kemampuan yang tinggi dalam menghambat pertumbuhan jamur $F$. Oxysporum penyebab penyakit layu pada tanaman tomat. Haryono dan Widiastuti (2001) menyatakan bahwa Trichoderma sp. merupakan salah satu jamur yang potensial untuk dikembangkan sebagai agens hayati pada beberapa jamur patogen tular tanah seperti Phytopthora dan Fusarium. Menurut Elfina et. al. (2001), mekanisme antagonis yang dimiliki Trichoderma sp dapat berupa kompetisi, mikoparasitisme dan antibiosis. Keefektifan jamur tersebut dalam menekan serangan penyakit adalah mampu berkembang biak sangat cepat, sehingga mampu berkompetisi dalam hal ruang dan makanan yang tersedia di sekitar perakaran. Mikroba antagonis akan menekan masuknya patogen melalui akar serta mengeluarkan senyawa kimia tertentu seperti antibiotik, toksin yang dapat menonaktifkan atau sekaligus mematikan mikroba patogen.

Mikroorganisme yang berperan dalam pertumbuhan tanaman termasuk dalam kelompok rhizobacteria yang hidup dan berkembang di daerah sekitar perakaran (rhizosfer) tanaman, baik yang simbiotik maupun non-simbiotik. Kelompok rhizobacteria ini diketahui dapat merangsang pertumbuhan tanaman dengan menghasilkan hormon tumbuh, asam asam organik, dapat memfiksasi nitrogen (Singh, 2013) dan sebagai biokontrol terhadap penyakit tanaman (Rai, 2006). Selain itu juga keberadaan rhizobacteria yang berperan sebagai pupuk hayati dapat menjadi satu faktor penting ketersediaan dan kelarutan hara bagi tanaman yang berdampak pada peningkatan produk sitanaman. Rizobakter dengan peranan yang telah disebutkan di atas termasuk dalam kelompok mikroba yang umumnya dikenal dengan Plant Growth Promoting Rhizobakteria (PGPR). Beberapa jenis mikroba yang termasuk dalam kelompok PGPR adalah Azotobacter sp., Azospirillum sp., Pseudomonas sp., Bacillus sp., dan Acetobactersp (Singh, 2013).

Plant Growth Promoting Rhizobacteria (PGPR) berpotensi meningkatkan produktivitas dan pertumbuhan tanaman. Ada beberapa cara meka- 
nisme PGPR dalam menstimulasi pertumbuhan tanaman. Mekanisme ini dikelompokkan menjadi dua yaitu secara langsung dan tidak langsung. Secara tidak langsung, rizobakteria terkait dengan produksi metabolit seperti antibiotik dan siderofor, yang dapat berfungsi menurunkan pertumbuhan fitopatogen. Secara langsung PGPR mampu memproduksi zat pengatur tumbuh dan meningkatkan pengambilan nutrisi oleh tumbuhan (Kloepper, 2004). Lebih lanjut dijelaskan oleh Klopper bahwa antagonisme antara rizobakteri dengan cendawan patogen dapat terjadi melalui mekanisme antibiosis, kompetisi, parasitisme/predatorisme, produksi enzim ekstraseluler, atau induksi resistensi.

Penelitian ini bertujuan untuk mengetahui efektivitas dari Trichoderma sp., PGPR serta kombinasi Trichoderma sp. dan PGPR terhadap perkembangan penyakit yang menyerang tanaman stroberi.

\section{METODE PENELITIAN}

Penelitian dilaksanakan di Desa Rurukan (Mahawu), Kecamatan Tomohon Timur, Kota Tomohon. Penelitian berlangsung sejak bulan Januari sampai dengan Oktober 2013.

Kegiatan penelitian dilakukan dengan beberapa tahapan sebagai berikut: 1) Perbanyakan Trichoderma sp. Trichoderma sp. yang digunakan adalah isolat lokal. Perbanyakan dilakukan di laboratorium Hama dan Penyakit Tumbuhan, Fakultas Pertanian, Universitas Sam Ratulangi Manado; 2) Pembuatan larutan PGPR. Cairan PGPR dibuat di laboratorium Hama dan Penyakit Tumbuhan, Fakultas Pertanian, Universitas Sam Ratulangi Manado. Bahan-bahan berupa akar bambu, terasi, gula merah, air cucian beras, kapur sirih diperoleh dari lapangan; 3) Persiapan Lahan, pemasangan mulsa plastik dan penanaman; 4) Aplikasi Trichoderma sp., Pupuk Kandang dan PGPR. Trichoderma sp. dan pupuk kandang terlebih dahulu dicampur sebelum diaplikasi di lapangan. Aplikasi Trichoderma sp., PGPR dan kombinasi Trichoderma sp. dan PGPR dilakukan sebanyak 3 kali dengan interval 2 minggu; 5) Rancangan percobaan yang digunakan. Percobaan menggunakan Rancangan Acak Kelompok dengan 4 perlakuan, sebagai berikut: Perlakuan
$\mathrm{A}=$ Trichoderma sp.; Perlakuan $\mathrm{B}=$ PGPR; Perlakuan $C=$ Kombination of Trichoderma sp. and PGPR; Perlakuan D = Control; Percobaan diulang sebanyak 4 kali; Data dianalisis dengan menggunakan software Minitab ver. 14; 6) Pengamatan: gejala serangan penyakit, jumlah tunas, berat akar dan berat buah stroberi.

\section{HASIL DAN PEMBAHASAN}

Hasil pengamatan di lapangan menunjukkan bahwa tingkat serangan penyakit pada tanaman stroberi sangat rendah. Sejak penanaman sampai panen, pada semua perlakuan, tidak dijumpai tanaman yang layu akibat serangan patogen penyebab penyakit. Namun demikian, dijumpai 5 tanaman dari total populasi stroberi yakni 1618 tanaman $(0.31 \%)$ yang menunjukkan gejala terserang oleh jamur Verticilium sp. Kelima tanaman yang diduga terserang oleh jamur Verticilium sp. tersebut tersebar pada perlakuan kontrol 2 tanaman dan masing-masing 1 tanaman pada perlakuan PGPR, perlakuan Trichoderma sp. dan perlakuan kombinasi PGPR dan Trichoderma sp. Rendahnya serangan patogen penyebab penyakit tersebut diduga bahwa varietas stroberi yang digunakan relatif tahan terhadap serangan penyakit.

Secara umum, penampilan tanaman stroberi sangat baik khususnya pada perlakuan PGPR, perlakuan Trichoderma sp. dan perlakuan kombinasi PGPR dan Trichoderma sp. Dibandingkan dengan perlakuan kontrol, tanaman stroberi terlihat agak kerdil. Rata-rata jumlah tunas dan berat akar (gr) tanaman stroberi pada ketiga perlakuan tersebut lebih tinggi dibandingkan dengan perlakuan kontrol.

Hasil analisis sidik ragam (menggunakan software Minitab ver. 14) menunjukkan bahwa perlakuan memberikan pengaruh yang sangat nyata terhadap jumlah tunas yang terbentuk $\left(p<\square_{0.05}\right)$. Hasil pengamatan jumlah tunas yang terbentuk pada masing-masing perlakuan menunjukkan perbedaan. Jumlah tunas terbanyak dijumpai pada perlakuan PGPR, rata-rata 6,2 tunas dan terendah pada perlakuan kontrol yakni 2,2 tunas. Rata-rata jumlah tunas yang terbentuk pada berbagai perlakuan dapat dilihat pada Tabel 1. 
Tabel 1 memperlihatkan bahwa ketiga perlakuan yakni perlakuan kombinasi, perlakuan Trichoderma sp., dan perlakuan PGPR menunjukkan perbedaan terhadap jumlah tunas yang terbentuk dibandingkan dengan perlakuan kontrol. Namun pada perlakuan Kombinasi menunjukkan jumlah tunas yang terbentuk tidak berbeda dengan perlakuan Trichoderma sp., akan tetapi perlakuan kombinasi menunjukkan jumlah tunas yang terbentuk berbeda dengan perlakuan PGPR.

Hasil analisis sidik ragam menunjukkan bahwa perlakuan memberikan pengaruh yang sangat nyata terhadap berat akar $\left(p<\square_{0.05}\right)$. Hasil pengamatan berat akar (gr) pada masing-masing perlakuan menunjukkan perbedaan. Berat akar tertinggi dijumpai pada perlakuan PGPR, rata-rata $68.75 \mathrm{gr}$ dan terendah pada perlakuan kontrol yakni 13.50 gr. Rata-rata berat akar pada berbagai perlakuan dapat dilihat pada Tabel 2.

Tabel 2 memperlihatkan bahwa ketiga perlakuan yakni perlakuan Trichoderma sp., perlakuan kombinasi Trichoderma sp. dan PGPR dan perlakuan PGPR menunjukkan perbedaan terhadap berat akar dibandingkan dengan perlakuan kontrol. Pada perlakuan Trichoderma sp. dan perlakuan kombinasi Trichoderma sp. dan PGPR, berat akar tidak berbeda namun berbeda dengan pada perlakuan PGPR.

Secara umum, jumlah tunas dan berat akar tanaman stroberi lebih baik perkembangannya pada perlakuan yang mengandung mikroorganisme

dibandingkan dengan pada perlakuan kontrol, tanpa mikroorganisme. Kondisi ini terjadi karena peran mikroorganisme itu sendiri. Kemampuan mikroorganisme yang terdapat dalam PGPR menghasilkan fitohormon membuat tanaman dapat menambah luas permukaan akar-akar halus, perkembangan tunas dan meningkatkan ketersediaan nutrisi di dalam tanah (Mia, et. al., 2010). Hasil penelitian Masnilah, $d k k$. (2007) menunjukkan bahwa perlakuan PGPR dapat meningkatkan pertumbuhan akar tanaman kedelai dibandingkan dengan perlakuan kontrol. Hal ini menyebabkan penyerapan unsur hara dan air dapat dilakukan dengan baik, sehingga kesehatan tanaman juga semakin baik. Dengan semakin baiknya kesehatan tanaman, ketahanan tanaman terhadap tekanan juga akan semakin meningkat. Baik tekanan karena faktor biotik seperti gangguan penyakit, maupun tekanan abiotik seperti suhu dan kelembaban. PGPR mampu meningkatkan pertumbuhan tanaman secara langsung melalui hormon-hormon partumbuhan yang dihasilkan seperti Giberelin (Gac) dan indole 3-acetic acid (IAA). IAA merupakan hormon pertumbuhan kelompok auksin yang berguna untuk merangsang pertumbuhan tanaman. Auksin berguna untuk meningkatkan pertumbuhan sel batang, menghambat proses pengguguran daun, merangsang pembentukan tunas dan buah, serta merangsang pertumbuhan kambium (Singh, 2013; Rai, 2006).

Tabel 1. Rata-rata Jumlah Tunas Stroberi yang Terbentuk pada Setiap Perlakuan (Table 1. The Average Number of Shoots Formed Strawberries on Each Treatment)

\begin{tabular}{clcc} 
No & \multicolumn{1}{c}{ Perlakuan } & Rata-rata & Notasi \\
\hline 1. & Kontrol & 2,20 & A \\
2. & Kombinasi Trichoderma sp. dan PGPR & 5,35 & B \\
3. & Trichoderma sp. & 5,88 & bc \\
4. & PGPR & 6,25 & C \\
\hline
\end{tabular}

Tabel. 2. Rata-rata Berat Akar (gr) Tanaman pada Setiap Perlakuan

(Table 2. The Average Weight of Roots ( $g$ ) at Each Treatment)

\begin{tabular}{clcc} 
No & \multicolumn{1}{c}{ Perlakuan } & Rata-rata $(\mathrm{gr})$ & Notasi \\
\hline 1. & Kontrol & 13.50 & $\mathrm{a}$ \\
2. & Trichoderma sp. & 57.50 & $\mathrm{~b}$ \\
3. & Kombinasi Trichoderma sp. dan PGPR & 58.75 & $\mathrm{~b}$ \\
4. & PGPR & 68.75 & $\mathrm{c}$ \\
\hline
\end{tabular}


Buah yang dipanen untuk ditimbang terdiri dari buah yang tidak rusak dan buah rusak. Kerusakan buah terjadi akibat adanya serangan tikus dan burung. Gejala yang terlihat yakni pada ujung buah terpotong dan terlihat adanya bekas gigitan. Hasil penimbangan didapatkan bahwa berat buah yang tidak rusak lebih berat dibanding buah yang rusak. Hasil penimbangan berat buah stroberi pada setiap perlakuan dapat dilihat pada Tabel 3 .

Tabel 3 menunjukkan bahwa hasil penimbangan rata-rata buah yang tidak rusak tertinggi pada perlakuan PGPR yakni $731.25 \mathrm{gr}$ dan terendah pada perlakuan kontrol sebesar $417.50 \mathrm{gr}$. Tingginya produksi buah pada perlakuan PGPR diduga disebabkan oleh aktivitas mikroorganisme yang terdapat didalamnya. Timmusk, et. al., 1999) mengemukakan bahwa sejumlah bakteri yang terdapat dalam PGPR dapat menghasilkan hormon auksin dan sitokinin yang dapat merangsang pembentukan buah, jika bersama IAA, sitokinin dapat merangsang pembelahan sel secara cepat (Tjondronegoro, et. al., 1989) sehingga pembentukan bobot buah bisa lebih baik.

Mekanisme secara langsung yang dilakukan oleh PGPR yaitu dengan cara mensintesis metabolit misalnya senyawa yang merangsang pembentukan fitohormon seperti indole acetic acid (IAA), atau dengan meningkatkan pengambilan nutrisi tanaman. IAA merupakan salah satu hormon pertumbuhan tanaman yang sangat penting. IAA merupakan bentuk aktif dari hormon auksin yang dijumpai pada tanaman dan berperan meningkatkan kualitas dan hasil panen. Fungsi hormon IAA bagi tanaman antara lain meningkatkan perkembangan sel, merangsang pembentukan akar baru, memacu pertumbuhan, merangsang pembungaan, serta meningkatkan aktivitas enzim (Arshad and Frankenberger, 1993).

\section{KESIMPULAN}

Tanaman stroberi tidak terserang oleh berbagai macam penyakit. Jamur Verticilium sp. dijumpai menyerang tanaman stroberi dengan intensitas yang sangat rendah.

Perlakuan PGPR, Perlakuan kombinasi Trchoderma sp. dan PGPR serta perlakuan Trichoderma sp. menunjukkan pengaruh yang sangat nyata terhadap jumlah tunas yang terbentuk dibandingkan pada perlakuan kontrol. Rata-rata jumlah tunas terbanyak dijumpai pada perlakuan PGPR yakni 6,25 tunas dan terendah pada perlakuan kontrol, yakni 2,20 tunas.

Perlakuan PGPR, perlakuan kombinasi Trchoderma sp. dan PGPR serta perlakuan Trichoderma sp. menunjukkan pengaruh yang sangat nyata terhadap berat akar yang terbentuk dibandingkan pada perlakuan kontrol. Rata-rata berat akar terberat dijumpai pada perlakuan PGPR yakni 68,75 gram dan terendah pada perlakuan kontrol, yakni 13,50 gram

Hasil penelitian menunjukkan bahwa berat buah yang tertinggi dijumpai pada perlakuan PGPR yakni 731,25 gram dan terendah pada perlakuan kontrol dengan berat buah 417,50 gram.

Tabel 3. Rata-rata Berat Buah (gr) Stroberi pada Setiap Perlakuan

(Table 3. Average Fruit Weight (g) in Each Treatment)

\begin{tabular}{llcc}
\hline \multicolumn{1}{c}{ Perlakuan } & $\begin{array}{c}\text { Buah Baik } \\
(\mathrm{gr})\end{array}$ & $\begin{array}{c}\text { Buah Rusak } \\
(\mathrm{gr})\end{array}$ & Total \\
\hline A. Trichoderma sp. & 613.75 & 93.75 & 707.50 \\
B. PGPR & 731.25 & 97.50 & 828.75 \\
C. Combination & 627.50 & 113.75 & 741.25 \\
D. Control & 417.50 & 63.75 & 481.25 \\
\hline
\end{tabular}


UCAPAN TERIMA KASIH

Terima kasih disampaikan kepada USAID, IPM-CRSP, Clemson University yang telah membiayai penelitian ini.

\section{DAFTAR PUSTAKA}

Arshad, M. and W.T. Frankenberger. 1993. Microbial Production of Plant Growth Regulator. pp. 307-347. In F.B. Melting (Ed). Soil Microbial Ecology. Applications in Agricultural and Environmental Management. Marcel Dekker, Inc. New York.

Baker, K.F and R.J. Cook. 1974. Biological Control of Plant Pathogens. San Fransisco: Freeman and Company.

Elfina, Y., T. Mardinus, Habazar dan A. Bachtiar. 2001. Studi Kemampuan Isolat-isolat Jamur Trichoderma spp yang Beredar di Sumatera Barat untuk Perngendalian Jamur Patogen Sclerotium rolfsii pada Bibit Cabai. Prosiding Kongres Nasional XVI dan Seminar IImiah, Perhimpunan Fitopatologi Indonesia. Bogor, 22-24 Agustus 2001.

Kloepper, J.W., C.M. Ryu, and S. Zhang. 2004. Induced Systemic Resistance Promotion of Plant Growth by Bacillus spp. Phytopatology 94: 1259-1266.

Kurnia, A. 2005. Petunjuk Praktis Budidaya Stroberi. Agromedia Pustaka. Jakarta.
Masnilah, R., P. A. Mihardja, dan T. Arwiyanto. 2007. Efektivitas Isolat Bacillus spp. Untuk Mengendalikan Penyakit Busuk Batang Berlubang Erwinia carotovora pada Tembakau di Rumah Kaca. Jurnal Mapeta 9 (3): 154-165.

Baset Mia, M.A., Z.H. Shamsuddin Z. Wahab and M. Marziah. 2010. Effect of Plant Growth Promoting Rhizobacterial (PGPR) Inoculation on Growth and Nitrogen Incorporation of Tissue-cultured Musa Plantlets under nitrogen-free hydroponics condition. Australian Journal of Crop Science (AJCS) 4 (2): 85-90. ISSN: 18352707.

Rai, M. K. 2006. Handbook of Microbial Biofertilizer. Food Production Press. New York.

Singh, Jay Shankar. 2013. Plant Growth Promoting Rhizobacteria (PGPR); Potential Microbes for Sustainable Agriculture. Resonance.

Sustiyah dan R.B. Mulyani. 2003. Pengujian Jamur Trichoderma spp dari Tanah Gambut Pedalaman sebagai Antagonis Terhadap Fusarium oxysporum. Lembaga Penelitian Unpar, Palangkaraya.

Timmusk, S., E. Tillberg, B. Nicander, dan U. Granhall. 1999. Cytokinin Production by Paenibacillus polymixa. Soil Biol. \& Biochem. 31: 1847-1852.

Tjondronegoro, P. D., M. Natasaputra, A. W. Gunawan, M. Djaelani, dan A. Suwanto. 1989. Botani Umum. Bogor: PAU IImu Hayat Institut Pertanian Bogor. 